\title{
THE PLACE OF THE SAINT LADISLAUS'MONARCHY IN THE MEDIEVAL EUROPE, ACCORDING TO THE WESTERN CHRONICLERS AT THE TIME OF THE FIRST CRUSADE
}

\begin{abstract}
A year after the death of Saint Ladislaus, large groups of pilgrims from Western Europe went through the Kingdom of Hungary to reach Constantinople as the first stage of the crusade. Although people had been travelling across Hungary on the way to Jerusalem since the period of Stephen I', in I096 Christians from the territories of the former Charlemagne's Empire met with fellow Christians from newly christianised Central Europe on an unprecedented scale ${ }^{2}$. Consequently, a modern historian has a possibility to explore a large collection of the Latin chronicles describing the First Crusade to investigate how social elite of Western Europe perceived the Kingdom of Hungary shortly after the long reign of Saint Ladislaus. This is the aim of this article: to search for opinions on the Kingdom of Hungary, its culture and place in Latin Europe in the descriptions of events during the crusader passage across Hungary.

Source material regarding the First Crusade is immensely abundant ${ }^{3}$. The Albert of Aachen's Historia Ierosolimitana and William of Tyre's Chronicon are of particularly great
\end{abstract}

\footnotetext{
* Dr Bartłomiej Dźwigała - adiunkt w katedrze historii średniowiecznej Instytutu Nauk Historycznych UKSW. Pracę doktorską przygotowaną pod opieką dr. hab. Marka K. Barańskiego pt. Sukcesja i inauguracja władzy w łacińskiej Jerozolimie. Studium nad narracjami opisującymi obejmowanie tronu przez nowego władcę w początkowym okresie istnienia Królestwa Jerozolimskiego w latach 1099-1118 obronił w 2015 r. na Wydziale Nauk Historycznych i Społecznych UKSW. Zainteresowania badawcze: dzieje wypraw krzyżowych i państw łacińskich w Syrii i Palestynie, problem legitymizacji władzy, łacińska średniowieczna literatura historiograficzna. Adres e-mail: b.dzwigala@uksw.edu.pl.

1 P. Engel, The realm of St Stephen: a history of medieval Hungary, 895-1526, transl. T. Palosfalvi, ed. A. Ayton, New York 2001, p. 35. On the social, cultural and religious situation in medieval Hungary vide: N. Berend, At the Gate of Christendom. Jews, Muslims and 'Pagans' in Medieval Hungary, c. 1000-c.1300, Cambridge 2001, pp. 340. Vide etiam: N. Berend, P. Wiszewski, P. Urbańczyk, Central Europe in the High Middle Ages. Bohemia, Hungary and Poland c. 900 - c.1300, Cambridge 2013, pp. 536.

2 Willelmi Tyrensis Archiepiscopi Chronicon, in: Corpus Christianorum. Continuatio Mediaevalis, vol. LXIII, ed. R. B. C. Huygens, Tournhout 1986, lib. I, 19, s. 143: „cum innumerabili exercitu transcursa Lotharingia, Franconia, Bavaria, et ea regione quae Austria dicitur, cum universa multitudine, quam ex omni populo, et tribubus, et linguis, et nationibus collegerat, quasi ad quadraginta millia, fines Hungarorum attigerat".

S. Edgington, The First Crusade: Reviewing the Evidence, in: The First Crusade: Origins and Impact, ed. J. Phillips, Manchester 1997, p. 57-77; J. Flori, Chroniqueurs et propagandistes: introduction critique aux sources de la Premiere croisade, Geneva 2010, p. 353; L. Russo, Le fonti della ,prima crociata”, in: Mediterraneo medievale. Cristiani, musulmani ed eretici tra Europa e oltremare (secoli IX-XIII), ed. M. Meschini, Milan 2001, p. 51-65; C. Kostick, Social Structure of the First Crusade, Leiden 2008, p. 9-95; Writing the Early Crusades: Text, Transmission and Memory, eds. M. Bull, D. Kempf, Woodbridge 2014.
} 
value because they contain detailed accounts showing the course of the events of the crusader passage through Hungary 4 . Other chronicles - both written by participants as well as those written later after the crusade using available materials - could be treated as complementary sources. Famous Gesta Francorum briefly mentions the journey of the crusader armies to Constantinople - the anonymous author after a short introduction immediately begins narrating events in the imperial capital city and Asia Minor ${ }^{5}$. Peter Tudebode, the author of a chronicle strongly related to Gesta Francorum, treats the passage across Central Europe in quite a similar way ${ }^{6}$. Another participant chronicler, Fulcher of Chartres 7 , marched in the Robert of Normandy, Robert of Flanders and Stephen of Blois milieu - that army chose a way through Italy and visited Rome, that's why Fulcher dwells upon papal affairs, which at that time were very complicated ${ }^{8}$. Raimund of Aguilers, the author of Historia Francorum Qui Ceperunt Iherusalem, was a chaplain to count Raimund of Tolouse and in his narrative he devotes some words describing the route through Slavonia and Dalmatia ${ }^{9}$ He omits to narrate other leaders' routes of marches. Among North French monks writing narratives on the First Crusade in its immediate aftermath, Baldric of $\mathrm{Dol}^{10}$ and Robert of Reims ${ }^{\text {II }}$ mentions in a few words events in the Balkans in I096, but Guibert of Nogent while narrating Peter the Hermit's passage through Hungary, stresses the Christian behaviour of the local inhabitants in the reception of pilgrims ${ }^{12}$. The epic chronicle entitled Historia Vie Hierosolimitane of Gilo of Paris and a second anonymous author is particularly worth mentioning - as it contains an abundance of material relevant to the topic ${ }^{13}$. Some sentences in the chronicle of Ekkehard of Aura are devoted to narrating the confrontation between King Coloman and the peasant crusade ${ }^{14}$.

As has already been mentioned there are two main sources that describe in a quite precise manner the crusaders passage through Hungary. Chronologically first is Historia Ierosolimitana of Albert of Aachen - written by an author who was not a participant of the first crusade. He

\footnotetext{
4 Albert of Aachen, Historia Ierosolimitana. History of the Journey to Jerusalem, ed. and trans. S. Edgington, Oxford 2007, lib. I, 6 - lib. II, 6, p. 8-70; Willelmi Tyrensis..., lib. I, 18, p. 140 - lib. II, 3, p. 165.

5 Gesta Francorum et aliorum Hierosolimitanorum. The Deeds of the Franks and the other Pilgrims to Jerusalem, ed. and trans. R. Hill, New York 1962, p. 2.

6 Petrus Tudebodus, Historia de Hierosolymitano Itinere, ed. J. H. Hill, L. L. Hill, Paris 1977, p. 33.

7 V. Epp, Fulcher von Chartres. Studien zu Geschichtsschreibung des ersten Kreuzzuges, Dusseldorf 1990.

8 A. Becker, Papst Urban II (1088-1099), Stuttgart 1988.

9 Raimundi de Agiles canonici Podiensis Historia Francorum qui Ceperunt Hierusalem, in: Recueil des historiens des croisades.Historiens occidentaux, vol. 3, Paris 1866, p. 235, 236. On the Raymond's route vide: T. Lecaque, 'Sclavonia etenim est tellus deserta et invia, et montuosa': Reassessing the Provençal Route through the Balkans on the First Crusade (unpublished conference paper available on Academia.edu: https://www.academia.edu/5067661/ Sclavonia_etenim_est tellus_deserta_et invia_et montuosa_Reassessing the Provençal_Route through the

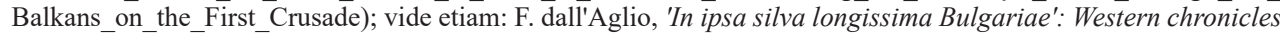
of the Crusades and the Bulgarian forest, „Bulgaria Mediaevalis”, vol. 1, 2010, p. 403-16.

10 Balderici episcopi Dolensis Historia Ierosolimitana, in: RHC Occ, vol. 4, Paris 1879, lib. I, 12, p. 20.

11 The Historia Iherosolimitana of Robert the Monk, ed. D. Kempf, M. Bull, Woodbridge 2013, p. 9.

12 Guiberti abbati Novigentis Gesta Dei per Francos, in: Corpus Christianorum. Continuatio Mediaevalis, vol. CXXVIIA, ed. R. B. C. Huygens, Turnhout 1996, lib. II, VIII, p. 122.

13 The 'Historia Vie Hierosolimitane' of Gilo of Paris and a second, Anonymous Author, ed. and trans. C. W. Grocock, J. E. Siberry, Oxford 1997, p. 25-53.

14 Frutolfi et Ekkehardi Chronica necnon Anonymi Chronica Imperatorum, ed. and trans. F-J. Schmale, I. Schmale-Ott, Darmstadt 1972, p. 144-148.
} 
based on oral relations collected from crusaders who were mostly members of the Godfrey's milieu. Work on the chronicle started in the immediate aftermath of the crusade and ended around II2O. In general, Albert of Aachen wrote the narrative on the First Crusade and the first I8 years of the Latin Kingdom of Jerusalem from the Lotharingian point of view. Consequently, Historia Ierosolimitana contains the precise description of Godfrey's passage across Hungary, but also unique information on the so-called peasant crusade, which is very interesting in the light of the present subject ${ }^{15}$.

William of Tyre is one of the most eminent intellectuals and writers of the Middle Ages. He was the archbishop of Tyre and the chancellor of the crusader kingdom as well as, by order of the King Amalric, preceptor of his son, future King Baldwin IV. King Amalric encouraged William to create a narrative on the First Crusade and the deeds of the Latin kings of Jerusalem. Furthermore, William was a member of the Jerusalem elite in the " 70 s and ' 80 s of the I2th century, consequently he shows us what was the common memory of the First Crusade in the Latin Kingdom ${ }^{16}$.

The relationship between the two main sources is really puzzling. Due to many elements that are common to William of Tyre and Albert of Aachen, historians have been trying to firmly establish a theory to explain the connections between both chronicles ${ }^{17}$. What we can deduce from the content is that William of Tyre had direct or indirect access to the first edition of Albert of Aachen Historia Ierosolimitana. This first edition is the history of the First Crusade - first six books of Aachen chronicle, which were in circulation in the first years after I099.

On 27th of November I095 pope Urban II at the end of the council in Clermont gave a speech to the gathered crowds in which he appealed to Latin Europe for the liberation of Jerusalem. The idea of crusading was propagated among medieval societies by the preachers - many of them gained popularity and became leaders of the groups of people marching towards Jerusalem across Europe ${ }^{\mathrm{I} 8}$.

The first of these groups was that of Walter Sansavoir. In May I096, he appeared with a great crowd of people at the gates of the Kingdom of Hungary. Albert of Aachen wrote:

„Ubi cognita est et audita illius animi intentione, et causa assumpte vie, a domno Kalamanno rege Christianissimo Ungariorum benigne susceptus est, et pacifice concessus est sibi transitus per universam terram regni sui, et emendi licentia."

[Once his purpose was heard and understood, and the reason the journey had been undertaken, he was graciously received there by Lord Coloman, the very Christian

\footnotetext{
15 P. Knoch, Studien zu Albert von Aachen. Der erste Kreuzzug in der deutschen Chronistik, Stuttgart 1966; S. Edginton, Introduction, in Albert of Aachen, Historia Ierosolimitana ..., p. xxi-xl

16 P. W. Edbury, J. G. Rowe, William of Tyre. Historian of the Latin East, Cambridge 1988; Willelmi Tyrensis..., p. 1-2; Cf. R. Hiestand, Zum Leben und zur Laufbahn Wilhelms von Tyrus, „Deutsches Archiv”, vol. 34, 1978, p. $345-380$.

17 S. Edgington, Albert of Aachen Reappraised, in: From Clermont to Jerusalem, ed. A. V. Murray, Turnhout 1998 , p. 55-68; Eadem, Introduction ..., p. xxiv.

18 J. Flori, Pierre l'Hermite et la premiere croisade, Paris 1999, p. 251-282; On the „people's crusade” vide: Thomas Asbridge, The First Crusade. A New History, London 2004, p. 89; J. France, Victory in the East. A Military History of the First Crusade, Cambridge 1994, p. 87-96; J. Rubenstein, Armies of Heaven. The First Crusade and the Quest for Apocalypse, New York 2011, p. 55-67.
} 
king of the Hungarians, who granted to him in peace passage through all the lands of his kingdom and a licence to buy food ${ }^{19}$.]

As Albert of Aachen stated, there were no problems for Walter and his army in Hungary. King Coloman allowed him to march across Hungary without any obstacles. It is worth pointing out that Coloman assumed such an attitude because he was aware of the aim of the expedition and pious intention of the pilgrims. Chronicler, by stressing this element, wants to assure the reader that the idea of crusading was not only understood but also fully accepted by the Hungarian monarch. Additionally, Albert uses the title ,rex christianissimus” in reference to Coloman the Learned, which is an unambiguous proof that for Albert a representative of an intellectual elite in Aachen - Hungarian monarchy was a member of the Latin Christendom at the end of the IIth century. In the view of Albert of Aachen, which is similar to the account of William of Tyre ${ }^{20}$, the King of Hungary shared with pilgrims from Germany and France the common values and outlooks on the contemporary situation of Christianity. Despite the easy passage across Hungary the army of Walter Sansavoir was destroyed by the Bulgarians when arrived at Belgrade.

The second large group was led by Peter the Hermit. He reached Sopron in the late May of the same year, which was the city on the Hungarian north-west border. Here he requested permission for a passage through Hungary. Guibert of Nogent, a famous French chronicler, wrote in his „Gesta Dei per Francos” that King Coloman had treated them like a Christian should treat other fellow Christians ${ }^{21}$. Guibert emphasizes the generosity of the Hungarians - the army of Peter the Hermit had all needed support. The accounts of Albert of Aachen and William of Tyre are in agreement with that of Guibert of Nogent. When Peter came to Zemun, on the south border of the Kingdom of Hungary, he learned the fate of Walter's army and because he felt threatened he gave orders to storm the city walls. Zemun was captured by Peter's army, and subsequently crusaders had to escape from Hungary to the Serbian lands, to avoid confrontation with Coloman's army. Peter managed to reach Constantinople, but in the end his peasant army was massacred by the Seljuks at Civetot.

There can be little doubt that western chroniclers perceived the Kingdom of Hungary as an equal part of Latin Christendom. The above-mentioned historians underlined bonds connecting Hungarian monarchy, baptized a hundred years before, with post-Carolingian communities. The common faith, shared principles of social life and a similar way of life were the basic unifying factors. It is evident that the elite of Western Europe had a positive attitude towards the Hungarian king despite the bloody clashes between the Hungarians and groups of crusaders. Chroniclers in many cases were on Coloman's side in describing his fights against the people's crusade. It means that the common values were stronger than the regional ties.

The next army of the so-called ,,people's crusade" was led by Godescalc. This group of crusaders committed a robbery on the Hungarians and because of that they were massacred by Coloman's troops, who earlier had ordered the crusaders to give up weapons in exchange

\footnotetext{
19 Albert of Aachen, Historia Ierosolimitana..., I, 6, p. 8-11.

20 Willelmi Tyrensis..., lib. I, 18, p. 141: „Eidem autem regno tunc preerat vir christianissimus rex Calemannus, qui cognito predicti Galteri adventu et de eius edoctus proposito, piam illius commendans intentionem eum benigne admisit et transitu suis expeditionibus per Hungariam concesso publicorum commerciorum gratiam non negavit". ${ }^{21}$ Guiberti abbati Novigentis Gesta Dei per Francos..., lib. II, VIII, p. 122: ,utpote Christiani Christianis”.
} 
for the guarantee of inviolability ${ }^{22}$. After these events, the next group of crusaders, an army of Emich of Flonheim, had no permission to enter Hungary. Crusaders decided to besiege Moson, a border Hungarian city. A huge battle took place with the main army of King Coloman, in which the crusaders were defeated and tried to flee, but the Hungarians took a bloody revenge and killed the majority of the pilgrims.

Albert of Aachen summarizes these dramatic events as follows:

„Hic manus Domini contra peregrinos esse creditur, qui nimiis inmundiciis et fornicario concubitu in conspectu eius peccaverunt, et exules Iudeos licet Christo contrarios, pecunie avaricia magis quam pro iusticia Dei gravi cede mactaverant, cum iustus iudex Deus sit, et neminem invitum aut coactum ad iugum fidei Catholice iubeat venire."

[In this the hand of God is believed to have been against the pilgrims, who had sinned in his eyes by excessive impurities and fornicating unions, and had punished the exiled Jews (who are admittedly hostile to Christ) with a great massacre, rather from greed for their money than for divine justice, since God is a just judge and commands no one to come to the yoke of the Catholic faith against his will or under compulsion ${ }^{23}$.]

This striking opinion gives an insight into the contemporary thinking on the abovementioned events. The chronicler decisively condemns the behaviour of the groups of peasant crusade, whilst the deeds of King Coloman were in accordance with the will of God. Coloman justly punishes the sins committed by groups of people's crusade ${ }^{24}$.

Duke Godfrey and his Lotharingian army came to the Hungarian border at the beginning of September $1096^{25}$. Then the negotiations started. King Coloman and Godfrey exchanged the envoys and letters, and they met personally to discuss the conditions of the crusader army's passage through the Kingdom of Hungary. Coloman guaranteed a safe passage across his monarchy with the possibility of buying food at the local markets. Duke Godfrey was obliged to give hostages as the warranty of peaceful behaviour of his followers. Among these hostages was Baldwin, Godfrey's younger brother and future king of Jerusalem, with his wife. The Lotharingian army marched through Hungary in friendly cooperation with local troops. When the crusaders reached the river Sava, which was treated as the south border of Arpad's monarchy, King Coloman the Learned released the hostages and said goodbye to Godfrey with a kiss of peace ${ }^{26}$.

Both Albert of Aachen and William of Tyre focus on the course of the negotiations between Duke Godfrey and King Coloman. They quote speeches and letters, which are particularly interesting from the perspective of this paper. Obviously, we cannot treat such quotations as

\footnotetext{
22 Albert of Aachen, Historia Ierosolimitana..., lib. I, 23-24, p. 44-49; Willelmi Tyrensis..., lib. I, 27-28, p. 153-155 .

23 Albert of Aachen, Historia Ierosolimitana ..., lib. I, 29, p. 56-59.

24 The similar view in: Willelmi Tyrensis..., lib. I, 29-30, p. 156-158.

25 H. Hagenmeyer, Chronologie de la premiere croisade, Hildesheim 1973, p. 37.

26 Albert of Aachen, Historia Ierosolimitana ..., lib. II, 7, s. 70-71: ,et ecce rex cum omni apparatu suo, et fratre ducis Baldwino eiusque uxore et cunctis obsidibus affuit, quos ibidem in manu ducis restituit, ac dehinc nimia dilectione commendato duce fratreque eius in donis plurimis et osculo pacis in terram regni sui reversus est." [they saw the king in all his state, with the duke's brother Baldwin and his wife and all the hostages, which he restored to the duke in the same place, and then he returned into his own kingdom, having commended the duke and his brother with very great love, which he showed by many gifts and the kiss of peace]; Willelmi Tyrensis..., lib. II, 3, p. 165.
} 
a precise copy of the original text, as they are elements of the narrative reflecting the views of the author. Nevertheless, these quotations reflect the perception of the Kingdom of Hungary among the western European elite at the beginning of the I2th century.

The main question of the discussion conducted by the Duke of Lorraine and the King of Hungary was about Coloman's attitude towards the crusade in the context of the people crusade's events. It is evident that the answer to this question had far more consequences for the general opinion on the Kingdom of Hungary.

Firstly, Duke Godfrey sent a legation bearing a letter to King Coloman. In this letter, he asked why the Hungarians, while being Christians, had treated the previous groups of the crusaders in such a cruel manner. In fact, the chroniclers through telling that story, had wanted to find out whether Hungary had been a part of the western Latin civilisation or not. The king replied that he had had to defend his kingdom against robbery and he stressed that a person who attacks his fellow Christian should not be treated as a Christian. Coloman stressed that he tried to cooperate and help crusaders, but it became impossible because of the violent behaviour of the pilgrims. Such explanations were given to the envoys with a letter addressed to Godfrey, which begins with these words:

„Rex Kalamannus duci Godefrido, et omnibus conchristianis salutem et dilectionem sine simulatione" 27

The Latin word „,conchristiani” expresses the fellowship on the basis of Latin Christianity, which is the essential element for understanding of the problem here discussed. The letter contained an invitation for a conference in Sopron. The king welcomed the duke on the bridge situated above swamps at the Hungarian border ${ }^{28}$. The scene of the friendly welcome on the bridge signifies the full membership of the Kingdom of Hungary in Latin Christendom.

A striking as well as neglected version of this story can be found in the Gilo of Paris' Historia Vie Hierosolimitane. According to Gilo, Godfrey was invited by Coloman to a conference at Szombathely, which is the place of birth of Saint Martin, bishop and confessor, patron of France. There was a great congress of Hungarian bishops, clergy, aristocrats to welcome Duke Godfrey, who, after the exchange of mutual kiss of peace, was led in solemn procession with relics, crosses and candlesticks to the sanctuary of Saint Martin. After that the conditions of the peaceful passage were established.

In conclusion, it is noticeable that at the beginning of the I2th century the Kingdom of Hungary was perceived as an equal member of Western civilisation. The groups of the socalled people's crusade and the Lotharingian army led by Duke Godfrey of Bouillon chose the route through Hungary as the imitation of the legendary pilgrimage of Charlemagne - as is expressed in the popular Gesta Francorum and the Peter Tudebode chronicle. There is no example of hostility towards Hungarians and the Hungarian king among the crusade

\footnotetext{
27 Albert of Aachen, II, 3, s. 64, 65: [King Coloman sends greetings and unfeigned love to Duke Godfrey and his fellow Christians.]; Willelmi Tyrensis..., lib. II, cap. 2, p. 164: „Sed et viros nobiles qui tecum sunt, zelo fidei Christianae accensos, credimus pium habere propositum. Unde et ea merita, quibus solent amici comparari, nolumus in nobis otiosa torpescere, sed omnibus debitam impendere caritatem et fraternae dilectionis erga eos operibus habundare parati sumus".

28 Albert of Aachen ....; Willelmi Tyrensis..., lib. II, 3, p.164: „Dux igitur, audita regis legatione habitoque suorum consilio, cum trecentis equitibus ex omni comitatu electis, die praefixa, ad locum pervenit destinatum. Ubi ponte transito, regem inveniens, ab eo benignissime, et cum multa susceptus est honorificentia."
} 
chroniclers even in describing clashes between Coloman's army and the crusaders. It is evident that the monarchy of Saint Stephen and King Ladislaus was perceived as built upon common European and Catholic foundations.

\section{The Place of the Saint Ladislaus' Monarchy in the Medieval Europe according to the Western Chroniclers at the time of the First Crusade Summary}

The present article examines the First Crusade's passage through the Kingdom of Hungary. Basing on the two main narrative sources: the Historia Ierosolimitana of Albert of Aachen and the chronicle of the William of Tyre the author comments on the relationship between the king of Hungary, Coloman the Learned, and Western European crusaders, which is the starting point to discuss a wider problem of opinion on newly christianizeed Hungary from the post-Carolingian Europe's point of view. As it has been shown, the Kingdom of Hungary at the time of the First Crusade was perceived as a member of Latin Christendom. Furthermore there is no evidence in contemporary Latin narrative sources for the chroniclers' negative approach towards Hunagarian Monarchy.

Keywords: Coloman the Learned, Hungary, First Crusade, William of Tyre, Albert of Aachen

\section{Miejsce monarchii św. Władysława w średniowiecznej Europie oczami kronikarzy opisujących pierwszą krucjatę}

\section{Abstrakt}

Niniejszy artykuł skupia się na przejściu pierwszej krucjaty przez Królestwo Węgier. Opierając się na dwóch głównych źródłach narracyjnych, jakimi są Historia Ierosolimitana Alberta z Akwizgranu oraz kronika Wilhelma z Tyru, Autor wnioskuje na temat relacji pomiędzy królem Węgier Kolomanem Uczonym a krzyżowcami z Europy zachodniej, co stanowi punkt wyjścia do refleksji nad szerszym problemem postrzegania nowo-ochrzczonych Węgier z perspektywy Europy post-karolińskiej. Artykuł udowadnia, że Królestwo Węgier w dobie pierwszej krucjaty było postrzegane jako część łacińskiego chrześcijaństwa. Co więcej, autorzy omawianych w tekście źródeł nie przyjmują negatywnego nastawienia względem węgierskiego monarchy nawet przy opisywaniu starć zbrojnych pomiędzy wojskiem węgierskim a grupami krzyżowców.

Słowa kluczowe: Koloman Uczony, Węgry, pierwsza krucjata, Wilhelm z Tyru, Albert z Akwizgranu

\section{BIBLIOGRAFIA}

Albert of Aachen, Historia Ierosolimitana. History of the Journey to Jerusalem, ed. and trans. Susan Edgington, Oxford 2007.

Frutolfi et Ekkehardi Chronica necnon Anonymi Chronica Imperatorum, ed. and trans. F-J. Schmale, I. Schmale-Ott, Darmstadt I972, p. I44-I48.

Gesta Francorum et aliorum Hierosolimitanorum. The Deeds of the Franks and the other Pilgrims to Jerusalem, trans. and ed. Rosalind Hill, New York 1962. 
Guiberti abbati Novigentis Gesta Dei per Francos, in: Corpus Christianorum. Continuatio Mediaevalis, vol. CXXVIIA, ed. R. B. C. Huygens, Turnhout 1996.

Petrus Tudebodus, Historia de Hierosolymitano Itinere, ed. J. H. Hill, L. L. Hill, Paris 1977. Raimundi de Agiles canonici Podiensis Historia Francorum qui Ceperunt Hierusalem, in: Recueil des historiens des croisades.Historiens occidentaux, vol. 3, Paris I866.

The 'Historia Vie Hierosolimitane' of Gilo of Paris and a second, Anonymous Author, ed. and trans. C. W. Grocock, J. E. Siberry, Oxford 1997.

The Historia Iherosolimitana of Robert the Monk, ed. Damien Kempf, Marcus Bull, Woodbridge 2013 .

Willelmi Tyrensis Archiepiscopi Chronicon, in: Corpus Christianorum. Continuatio Mediaevalis, vol. LXIII, ed. R. B. C. Huygens, Tournhout 1986.

Asbridge Thomas, The First Crusade. A New History, London 2004.

Balderici episcopi Dolensis Historia Ierosolimitana, in: RHC Occ, vol. 4, Paris I879.

Becker Alfons, Papst Urban II (I088-I099), Stuttgart 1988.

Berend Nora, At the Gate of Christendom. Jews, Muslims and 'Pagans' in Medieval Hungary, c. I000-c.I300, Cambridge $200 \mathrm{I}$.

Berend Nora, Wiszewski Przemysław, Urbańczyk Przemysław, Central Europe in the High Middle Ages. Bohemia, Hungary and Poland c. 900 - c.I300, Cambridge 2013.

dall'Aglio Francesco, 'In ipsa silva longissima Bulgariae': Western chronicles of the Crusades and the Bulgarian forest, „Bulgaria Mediaevalis”, vol. I, 20I0, p. 403-I6.

Edbury Peter, Rowe John Gordon, William of Tyre. Historian of the Latin East, Cambridge I988.

Edgington Susan, Albert of Aachen Reappraised, in: From Clermont to Jerusalem, ed. Alan V. Murray, Turnhout I998, p. 55-68.

Edgington Susan, The First Crusade: Reviewing the Evidence, in: The First Crusade: Origins and Impact, ed. Jonathan Phillips, Manchester I997, p. 57-77.

Engel Pal, The realm of St Stephen: a history of medieval Hungary, 895-I526, transl. Tamás Pálosfalvi, ed. Andrew Ayton, New York 200I

Epp Verena, Fulcher von Chartres. Studien zu Geschichtsschreibung des ersten Kreuzzuges, Dusseldorf i990.

Flori Jean, Chroniqueurs et propagandistes: introduction critique aux sources de la Premiere croisade, Geneva 2010.

Flori Jean, Pierre l'Hermite et la premiere croisade, Paris 1999.

France John, Victory in the East. A Military History of the First Crusade, Cambridge I994. Hagenmeyer Heinrich, Chronologie de la premiere croisade, Hildesheim 1973.

Hiestand Rudolf, Zum Leben und zur Laufbahn Wilhelms von Tyrus, „Deutsches Archiv”, vol. 34, I978, p. 345-380.

Jay Rubenstein, Armies of Heaven. The First Crusade and the Quest for Apocalypse, New York 20II.

Knoch Peter, Studien zu Albert von Aachen. Der erste Kreuzzug in der deutschen Chronistik, Stuttgart 1966.

Kostick Conor, Social Structure of the First Crusade, Leiden 2008.

Russo Luigi, Le fonti della ,prima crociata”, in: Mediterraneo medievale. Cristiani, musulmani ed eretici tra Europa e oltremare (secoli IX-XIII), ed. Marco Meschini, Milan 200I, p. 5I-65.

Writing the Early Crusades: Text, Transmission and Memory, eds. Marc Bull, Damien Kempf, Woodbridge 2014. 